\title{
"CHRONIC SORROW THEORY APPLICATION" TO OVERCOME THE FEELING OF LOSS DUE TO INFANT MORTALITY IN POST-PARTUM WOMEN
}

\author{
Dedeh Sri Rahayu \\ Stikes Budi Luhur Cimahi \\ Corresponding email: defizi2011@gmail.com
}

\begin{abstract}
Data from the World Health Organization (WHO) in 2012 stated that $44 \%$ of infant deaths in the world occurred in the first 28 days of life (neonatal period). The research results of the Central Statistics Agency (CSA) in 2016 noted that the infant mortality rate (IMR) reached $25.5 \%$, West Java Province was one of the contributors to the highest maternal mortality rate (MMR) and infant mortality rate (IMR). Infant mortality inside the womb or outside the womb triggers grief and deep sorrow that is at risk of progressive, repetitive and permanent in women. Nurses in the maternity area play an important role in overcoming the problem of loss through various approaches to either theory or intervention. The purpose of this study was to determine the application of chronic sorrow theory in post-partum women whose babies were dead at Sariningsih Hospital Bandung. Method: This research was qualitative research. Participants were 5 people selected using purposive sampling techniques. Data collection was done by interviewing using a guide from the Burke / Eakes Chronic Sorrow Assessment Tool. Results: It was identified that women's opinions about the causes of infant mortalities were planned (abortion) and unplanned. Participants had effective coping strategies in dealing with their loss such as social support, and spiritual beliefs for comfort. Conclusion: participants felt the effectiveness of the chronic sorrow theory to overcome infant loss.
\end{abstract}

Keywords: chronic sorrow theory application, loss, post-partum women, Qualitative.

\section{INTRODUCTION}

Individuals in this world must feel deep sadness when a friend or relative passed away, including the death of an infant when they are still in the intrauterine or already born. In the human life cycle, individuals may be faced with situations that can occur continuously if an event occurs. Adverse experiences lead to imbalances between expected and challenges. This event causes grief / deep sadness or long-lasting sorrow, seeps inside the individual, repetitive and permanent.

Data from the world health organization (2012), states, $44 \%$ of infant deaths in the world occur in the first 28 days of life (neonatal period). The research results by the Indonesian statistical center (2016) noted that the infant mortality rate (IMR) reached 25,5. The highest 
Dedeh Sri Rahayu : "Chronic Sorrow Theory Application" to Overcome

infant mortality rate occurred in 2012 , reaching $28 \%$ of deaths per 1,000 babies born. West Java Province is one of the highest contributors to maternal mortality (MMR) and infant mortality (IMR). In a discussion held by the United States Aids for International (USAID) with the West Java Ministry of Health. The number of deaths in newborns increased from 3,098 cases in 2014 to 3,369 cases in 2015. (Ministry of Health, 2016).

Data on fetal or infant mortality in Sariningsih Bandung hospital from September to December 2017 and January 2018 as many as 12 people. Gravida starts from the third week to mature (aterm) of week 42. Treatment is expected to support individuals in adapting with lost and developing positive coping mechanisms. Previous research was conducted by the Mujahideen of Zakiyah, et al., 2015 stated that the response of participants who emerged after the death of their baby was to rise from sadness. Nurses in the maternity area play an important role in overcoming the problem of loss with various methods of intervention. The purpose of this study is to find out the application of chronic sorrow theory in post-partum women with lost of babies.

\section{METHODS}

The type of this research was qualitative research. Participants were 5 people who were selected using purposive sampling techniques, with the criteria of postpartum women who had experienced fetuses or babies mortality at Sariningsih Hospital Bandung. Data collection was done by interviewing using a guide from the Burke / Eakes Chronic Sorrow Assessment Tool. Data were analyzed using thematic analysis for the qualitative study.

\section{RESULTS}

The results of the study identified 2 topics namely the causes of infant mortality and the application of chronic sorrow theory

\section{The causes of infant mortality}


Participants said the cause of the infant's death was because they were too tired of work or household matters. A participant said that as a worker in a restaurant she often walked to deliver food to customers or take dirty glasses and dishes and clean up at restaurants. Another woman said that she often walked quickly when she worked, did not remember that she was pregnant, '...the problem was tired, from dawn to $9 \mathrm{pm}$, I walked like I am no longer pregnant, very quick and rush...' A mother said that she often went back and forth to her room at the second level of her house. The last mother said she was tired working daily as a food seller or groceries with her husband. The participant said that at first, she did not believe her fetus was dead, felt angry with the condition, tried to convince herself, felt hopeless and depressed, and finally could accept the death of her fetus.

\section{The application of the chronic sorrow theory}

This theory focuses on the behavior of the normal response to the loss experienced especially fetal loss. Participants in this study behaved normally in the face of fetal loss, because of the support of the social system. The results of the interview showed that all participants received social support. The source of the support obtained comes from the closest people, such as husband, family, friends or neighbors, and colleagues. The support received is basically aimed at encouraging not to be sad. This was said by the participants "... my husband supports, he states this is a destiny from God, must be accepted". Other participants expressed their support from her husband "husband did not consider this my fault, instead, he said this was a trial from God and we must be patient and accepting"

The coping strategy performed by participants facing the death of their infant is by visiting and discussing with the health worker. All participants went to the health worker at Sariningsih hospital because of bleeding complaints, the baby did not grow and felt pain and heat in the waist area.

\section{DISCUSSION}

Participants who experienced loss due to infant deaths conceived at 3 to 10 weeks' gestation or usually called abortus and babies passed away at birth called IUFD or intra-uterine fetal death. This situation is included as the maturational loss which requires treatment with chronic sorrow theory. As Potter, 2009 noted, the maturational loss is a sense of loss that causes or experiences 
Dedeh Sri Rahayu : "Chronic Sorrow Theory Application" to Overcome

permanent changes in life and threatens our feelings about ownership and security. Example: Death of a loved one, divorce.

Effective management in dealing with mothers who experienced loss could be performed internally (individual coping strategies) or externally (health worker assistance/intervention). According to Eakes et al., 1998 in Alligood, 2014 that Chronic sorrow will not weaken individuals if its methods effectively manage so they are able to control feelings of sadness both internally and externally. Mothers who experienced loss must be supported by the closest family such as husband, parents or siblings, and even the grown-up child can be her motivation. Close and far neighbors could motivate mothers who felt a deep loss, so sadness will disappear or decrease slowly.

Colleagues at work, social or religious activities could motivate mothers so that maternal coping is effective in overcoming sadness so that it will not be a chronic problem. Think positively in overcoming disaster and receive wisdom that Allah will give the best behind that all. As discovered by Hainsworth, 1994 in Alligood, 2014 that Cognitive Strategy involves efforts to change the attitudes and focus of someone who is exposed to chronic sorrow to be more positive in their life.

Postpartum women who lost their babies shared their experiences with mothers who had similar experiences, close friends, and health workers. So that she feels more comfortable, supported and can even distract her sadness. The good strategy is as expressed by Eakes, 1993; Hainsworth, 1994, in Alligood, 2014, that interpersonal strategies include individual efforts by telling experiences with close friends or trusted professionals in order to establish group support. An example of interpersonal coping is going to a health worker, entering into a group and talk or communicate with other people.

Mothers who lost their children at the initial stage or stage of rejection need special care by health workers. This is as expressed by Isaksson \& Ahlstrom, 2008 that external management is important with the assumption that chronic sorrow that afflicts an individual is a normal event. This assumption is very important and becomes the basis for every intervention given by nurses. A nurse is also required to acknowledge and accept the feelings of individuals who experience chronic sorrow. Nurses help to build awareness and to guide in understanding 
Dedeh Sri Rahayu : "Chronic Sorrow Theory Application" to Overcome

the meaning of losing individuals so that individual coping (Internal management) is also strengthened and supported by nurses.

According to Isaksson \& Ahlstrom, 2008 also stated that health workers or nurses can provide intervention to the family by providing information and advice. The family can be a listener, mentally support the mother and prevent sadness. The initial stage of feeling loss is the refusal to an unwanted event such as losing a baby, health worker or nurse must be more careful to this stage so that participants felt ease to cope with the next stage, anger. Participants do not feel rage or can control their anger and even disappointment can be avoided. Participants do not blame family or health workers in this matter. Participants also did not regret the death of the coveted and loved child.

Health workers or nurses would then deal with the fourth stage which is depression, in this stage mothers will have a feeling of inability to take care of the baby they contained, feeling sensitive, deep feelings of trauma, feeling alone and difficult to forget. According to Videbeck (2008), this stage is often encountered by remembering something that has occurred. Therefore, nurses play an important role in entertaining participants and diverting their sadness.

The stages of acceptance are the final stage of the grieving stages discovered in few participants. At this stage, the participants are forbearing over the loss and surrender to God. As Karger (2014) stated in his research that at this stage a person rediscovers hope for their future. This is as expressed by some participants. The role of the nurse is to advise participants to be more careful in the next pregnancy and suggest always checking their womb to the health worker or suggesting ultra-sonography (USG) so that they know the condition of the baby they contain.

Nurses provide motivation to get closer to God/increase the time spent for worshiping. This is in accordance with Karger's research (2014) in his research that faith and spirituality dispel sadness so that someone who is in the process of grieving does not fall in a bad condition. Currie (2014) stated that parents who lost their children try to use coping strategies to rationalize a loss, by asking questions about the existence of human life (why humans live, where humans will live afterlife, etc.). This is performed so that parents understand the meaning of death and are fully aware that she is not the owner of life. 
Dedeh Sri Rahayu : "Chronic Sorrow Theory Application" to Overcome

In addition to this, several participants distract themselves by working, sharing with others, seeking entertainment and accepting passively. Work means utilizing one's potential to divert the mind so that concentration is not centered on loss and grieving as is done by several participants while other participants share with the environment means utilizing a support system that is around participants to divert feelings of loss and grieving. Another way that can be done is to seek entertainment and accept passively by trying not to think about losing and replacing it with other things.

\section{CONCLUSION}

Participants experienced loss and revealed the cause of loss, participants with the support of social families and officers applied chronic sorrow theory and effectively managed the sense of loss experienced. It is necessary to develop effective internal and external management to overcome loss and prevent chronic or permanent grief.

\section{REFERENCES}

Benedict, M. M. \& Montgomery. (2013). Our Spirits, Ourselves: The Relationships between Spiritual Intelligence, Self-Compassion, and Life Satisfaction. A dissertation in Partial Fulfillment of the Requirements of the Degree Doctor of Philosophy. Alliant International University. September. 2013.

Carlo, W.A., et al. (2010). Newborn-Care Training and Perinatal Mortality in Developing Countries. 362:615

Currie, E. R. ( 2014). Parent Perspectives of Neonatal Intensive Care At The End Of Life And Subsequent Bereavement And Coping Experiences After Infant Death. A Dissertation Submitted To The Graduate Faculty of The University of Alabama At Birmingham, In Partial Fulfillment of The Requirements For The Degree Of doctor of Philosophy. University of Alabama, Birmingham. 2014.

Dyregrov, K., Dyregrov, A., Johnsen, I. (2013). Positive And Negative Experiences From Grief Group Participation: A Qualitative Study. 68 (1), 45-62. Flenady, V., et al. (2014). Meeting the needs of parents after a stillbirth or neonatal death. 121 (Suppl. 4): 138.

Eakes, Burke, Hainworth, 1999. Chronic Sorrow. St. Louis: Mosby Elsevier, Inc...

Gordon, J. (2009). An Evidence-Based Approach For Supporting Parents Experiencing Chronic Sorrow. Pediatric Nursing. 35 (2). 
Dedeh Sri Rahayu : "Chronic Sorrow Theory Application" to Overcome

Grunnet \& Alden. (2008). The meaning of her child's death: A mother's experience of grief.

Dissertation Submitted to the Faculty of the Institute for Clinical Social Work in Partial Fulfillment for the Degree of Doctor of Philosophy, Chicago, Illinois. March. 2008.

Harris, J. (2015). A Unique Grief. International Journal of Childbirth Education. 30 (1), 82.

Karger, M. (2014). Exploring Mothers' Experiences Over Time Following Death of Their Young Child From Cancer: Implications For Practice. A Dissertation Submitted In Partial Fulfillment of The Requirements For The Degree of Doctor of Psychology. The University of New Jersey. October. 2014.

Jensen, Bobak Lowdermik. 2005. Buku Ajar Keperawatan Maternitas. Jakarta : EGC.

Mujahidah Zakiyah, 2015. Pengalaman kehilangan dan berduka pada ibu yang mengalami kematian bayi di Depok. Jurnal Keperawatan Jiwa volume 3 no. 2 tahun 2015

Notoatmodjo S (2005). Metodologi penelitian kesehatan, Jakarta : Rineka Cipta

Olivas, L. (2013). After-Death Communication: A Parent Who Has Lost a Child. Dissertation Submitted in Partial Fulfillment of the Requirements for the Degree of Doctor of Philosophy Counseling Psychology. Walden University November. 2013.

Peterson \& Bredow. 2013. Middle range Theory: Application to Nursing Research 3rd Edition. Wolter Kluwer Health. Philadelphia

Potter \& Perry. 2009. Fundamental of Nursing. Jakarta. Salemba Medika

Research 3rd Edition. Wolter Kluwer Health. Philadelphia

Riyanto Agus, 2013. Metodologi Penelitian Kesehatan. Salemba Medika

Tomey, A. M. \& Alligood, M. R. (2010). Nursing Theorists and Their Works (7thed.). St. Louis: Mosby Elsevier, Inc...

Varney, Helen. 2007. Buku Ajar Asuhan Kebidanan Edisi IV Volume 1. Jakarta : EGC.

WHO. 2014, Infant Mortality Situation And Trends. http://www.who.int, diperoleh tanggal 22 november 2014). Jawa Barat penyumbang terbesar angka kematian bayi di Indonesia oleh Artanti Hendriyana (2013, http://www.unpad.ac.id, diperoleh tanggal 24 November 2014).

Wiknjosastro, Hanifa. 2008. Ilmu Kandungan. Jakarta : PT. Bina Pustaka

Wilkinson \& Ahern.2012. Prentice Hall Nursing Diagnosis Handbook: Nanda Diagnoses, NIC Interventions, NOC Outcomes. Jakarta:EGC. 